\title{
Diagnostic value of fine needle aspiration cytology in the evaluation of soft tissue tumours
}

\author{
Suman Singh ${ }^{1, *}$, Jaishree Sharma ${ }^{2}$, Kavita Mardi ${ }^{3}$, Kamaljeet Singh Jaswal $^{4}$, Rakesh Panwar ${ }^{5}$ \\ ${ }^{1}$ Assistant Professor, ${ }^{2-4}$ Professor, ${ }^{5}$ Senior Resident, Dept. of Pathology, ${ }^{1}$ Dr. Rajendra Prasad Government Medical College \\ Tanda, Himachal Pradesh, ${ }^{2,5}$ Dr. Yashwant Singh Parmar Government Medical College, Nahan, Himachal Pradesh, ${ }^{3}$ Indira \\ Gandhi Medical College, Shimla, Himachal Pradesh, ${ }^{4}$ Maharishi Markandeshwar Medical College and Hospital, Maharishi \\ Markandeshwar University, Kumarhatti Solan, Himachal Pradesh, India
}

*Corresponding Author:

Email: csuman9@gmail.com

\begin{abstract}
Context: Fineneedle aspiration cytology (FNAC) is an important tool in the diagnosis of soft tissue tumours. The method is widely tested in recent years as it is easy, quick, safe and fast compared to histopathology.

Aims: Present study is being conducted to study the cytomorphological patterns of soft tissue tumours and find out the efficacy of FNACwhen compared with histopathology aided with immunostains.

Settings and Design: Fifty six cases presented with soft tissue swellings were subjected to FNAC. The results were compared with histopathology aided with immunohistochemistry.

Materials and Methods: Present study was a prospective study conducted between July 2007 and December 2008 for a period of one and a half year in the department of Pathology of a tertiary care institute. Patients who presented with soft tissue tumours were included in the study. Patients with inflammatory swellings and those in which histopathology was not available were excluded. Fifty six cases presented with soft tissue swelling were subjected to fine needle aspiration (FNA). Findings were compared with histopathology. Immunohistochemistry was used in some cases for exact diagnosis.

Statistical analysis used: sensitivity, specificity, positive predictive value, negative predictive value and diagnostic accuracy.

Results: In the primary diagnosis of soft tissue tumours by FNAC, the study showed sensitivity and specificity of $93.75 \%$ and $94.4 \%$ for malignancy. Overall diagnostic accuracy was $94.4 \%$ for both benign and malignant neoplasms. Positive predictive value and negative predictive value was $88.24 \%$ and $97.3 \%$ for malignancy.

Conclusions: FNA of soft tissue tumours yields specific architechtectural patterns and cytological details. FNAC helps in the initial management of soft tissue tumours as it is rapid and fairly accurate.
\end{abstract}

Keywords: Soft issue tumours, Cytology, Patterns, Histopathology.

Key Messages: Careful interpretation of cytological findings is required for accurate diagnosis of soft tissue tumours. Different types of tumours having similar cell pattern poses diagnostic difficulties.

\section{Introduction}

FNAC is a valuable tool in the diagnosis of soft tissue tumours and has been widely tested in recent years. ${ }^{1-11,16-19}$ Benefits of FNAC over coarse needle or open surgical biopsy are rapid preliminary diagnosis without hospitalisation and anaesthesia, negligible complication and fear for tumour spread. ${ }^{5}$ Precise diagnosis of significant number of tumours is possible by taking into account architectural patterns, cytological details and clinical characters of lesion. ${ }^{11}$

Present study is being conducted to ascertain the diagnostic value of FNAC in the evaluation of soft tissue tumours by studying various cytomorphological patterns and classify the tumours as benign or malignant and to subtype the tumour wherever possible. The results were compared with histopathology aided with immunostains.

\section{Materials and Methods}

Present study was conducted between July 2007 and December 2008 in the department of Pathology of a tertiary care institute. Fifty six cases presented with soft tissue swelling were subjected to FNA. Aspiration was done using 21-23 gauge needle and 20ml disposable syringe. No local anaesthesia was used. Geimsa stain was used in all while per iodic acid schiffs (PAS) stain in few cases. All the cases were subjected for histopathological examination (HPE) aided with immunostains for final diagnosis. FNAC was then correlated with histopathology to ascertain the diagnostic accuracy of cytology.

\section{Results}

Of 56 cases with soft tissue swelling, 54 cases were of soft tissue tumours. One case was inconclusive due to hemorrhagic smears and other was organised abscess. Thirty nine (72\%) were found to be benign and $16(28 \%)$ were malignant on histopathology Table 1. Out of 54 cases, specific diagnosis was given to 52 cases while two cases were reported as benign spindle cell neoplasm. The age distribution showed that the benign tumours occurred above second decade of life, while soft tissue sarcoma occurred in patients of all ages Table 1. For benign tumours trunk was the commonest site followed by extremities whereas malignant tumours were common in lower extremities followed by trunk. Both on cytology and on histopathology benign tumours showed spindle and 
mature tissue pattern while malignant tumours showed pleomorphic, spindle and round cell pattern Table 2 . Histopathology of eight cases required immunohistochemistry for type specific diagnosis Table 3. The results of FNAC and histopathology were compared and analysed Table 4 and Table 5. The study showed sensitivity and specificity of $93.5 \%$ and $94 \%$ respectively with overall diagnostic accuracy of $94.4 \%$. FNAC was more specific than sensitive in diagnosing malignant tumours Table 6.

Table 1: Type and age wise distribution of soft tissue tumors

\begin{tabular}{|c|c|c|c|c|c|c|c|}
\hline \multirow{2}{*}{$\begin{array}{l}\text { Type } \\
\text { Benign } \\
\text { tumour (B) }\end{array}$} & \multicolumn{2}{|c|}{ Subtype } & \multicolumn{5}{|c|}{ Age distribution (in years) and number } \\
\hline & & & $0-10$ & 11-20 & $21-40$ & $>40$ & $\begin{array}{l}\text { All age } \\
\text { groups }\end{array}$ \\
\hline & 1 & Lipoma & & & 14 & 14 & 28 \\
\hline & 2 & Schwannoma & & & 3 & 3 & 6 \\
\hline & 3 & Neurofibroma & & & 2 & & 2 \\
\hline & 4 & Cavernous hemangioma & & & 2 & & 2 \\
\hline & 5 & Fibroma & & & 1 & & 1 \\
\hline \multirow{7}{*}{$\begin{array}{l}\text { Malignant } \\
\text { tumors (M) }\end{array}$} & 1 & Pleomorphic sarcoma & & & 2 & 3 & 5 \\
\hline & 2 & $\begin{array}{l}\text { Malignant Peripheral nerve } \\
\text { sheath tumors(MPNST) }\end{array}$ & & & 1 & 2 & 3 \\
\hline & 3 & Ewings sarcoma & 1 & 1 & 1 & & 3 \\
\hline & 4 & Synovial sarcoma & & & 2 & & 2 \\
\hline & 5 & Rhabdomyosarcoma(RMS) & 1 & & & & 1 \\
\hline & 6 & Leiomyosarcoma(LMS) & & & & 1 & 1 \\
\hline & 7 & $\begin{array}{l}\text { Liposarcoma/Atypical } \\
\text { lipoma }\end{array}$ & & & 1 & & 1 \\
\hline
\end{tabular}

Table 2: Cytological patterns observed in soft tissue tumours

\begin{tabular}{|l|l|}
\hline Pattern & No. and Type of tumour \\
\hline Benign tumour (B) & $\begin{array}{l}11 \text { (schwannoma, neurofibroma, fibroma, } \\
\text { fibrolipoma, cavernous hemangioma) }\end{array}$ \\
\hline Spindle cell & 27 (lipoma) \\
\hline Mature tissue & $\begin{array}{l}\text { Pleomorphic } \\
\text { 5),LMS(1),MPNST (1) }\end{array}$ \\
\hline Malignant tumours (M) & $\begin{array}{l}\text { MPNST (2), synovial sarcoma (2), } \\
\text { atypical lipoma/liposarcoma (1) }\end{array}$ \\
\hline Pleomorphic & Ewing's sarcoma (3), RMS (1) \\
\hline Spindle
\end{tabular}

Table 3: Tumors in which immunohistochemistry aided/confirmed the histopathological diagnosis

\begin{tabular}{|l|l|c|c|c|}
\hline S. No & FNAC Diagnosis & $\begin{array}{c}\text { Histopathological } \\
\text { diagnosis }\end{array}$ & $\begin{array}{c}\text { Markers } \\
\text { used }\end{array}$ & Final diagnosis \\
\hline 1 & MPNST & MPNST & S-100+ & MPNST \\
\hline 2 & $\begin{array}{l}\text { Low Grade } \\
\text { Myxofibrosarcoma }\end{array}$ & NEUROFIBROMA & S-100+ & NEUROFIBROMA \\
\hline 3 & Pleomorphic sarcoma & Pleomorphic sarcoma & $\begin{array}{c}\text { SMA+, } \\
\text { CD68- }\end{array}$ & LMS \\
\hline 4 & MPNST & MPNST/SS & $\begin{array}{c}\text { S-100+, } \\
\text { SMA- }\end{array}$ & MPNST \\
\hline 5 & Pleomorphic sarcoma & Pleomorphic sarcoma & S-100+ & MPNST \\
\hline 6 & Ewing's Sarcoma & Ewing's Sarcoma & $\begin{array}{c}\text { MIC- } \\
2+, \text { VIM+ }\end{array}$ & Ewing's Sarcoma \\
\hline 7 & Ewing's Sarcoma & Ewing's Sarcoma/RMS & $\begin{array}{c}\text { MIC-2+, } \\
\text { MYOG- }\end{array}$ & Ewing's Sarcoma \\
\hline 8 & RMS & RMS & MYOG+ & RMS \\
\hline
\end{tabular}


Table 4: Comparative analysis of FNAC and histological diagnosis

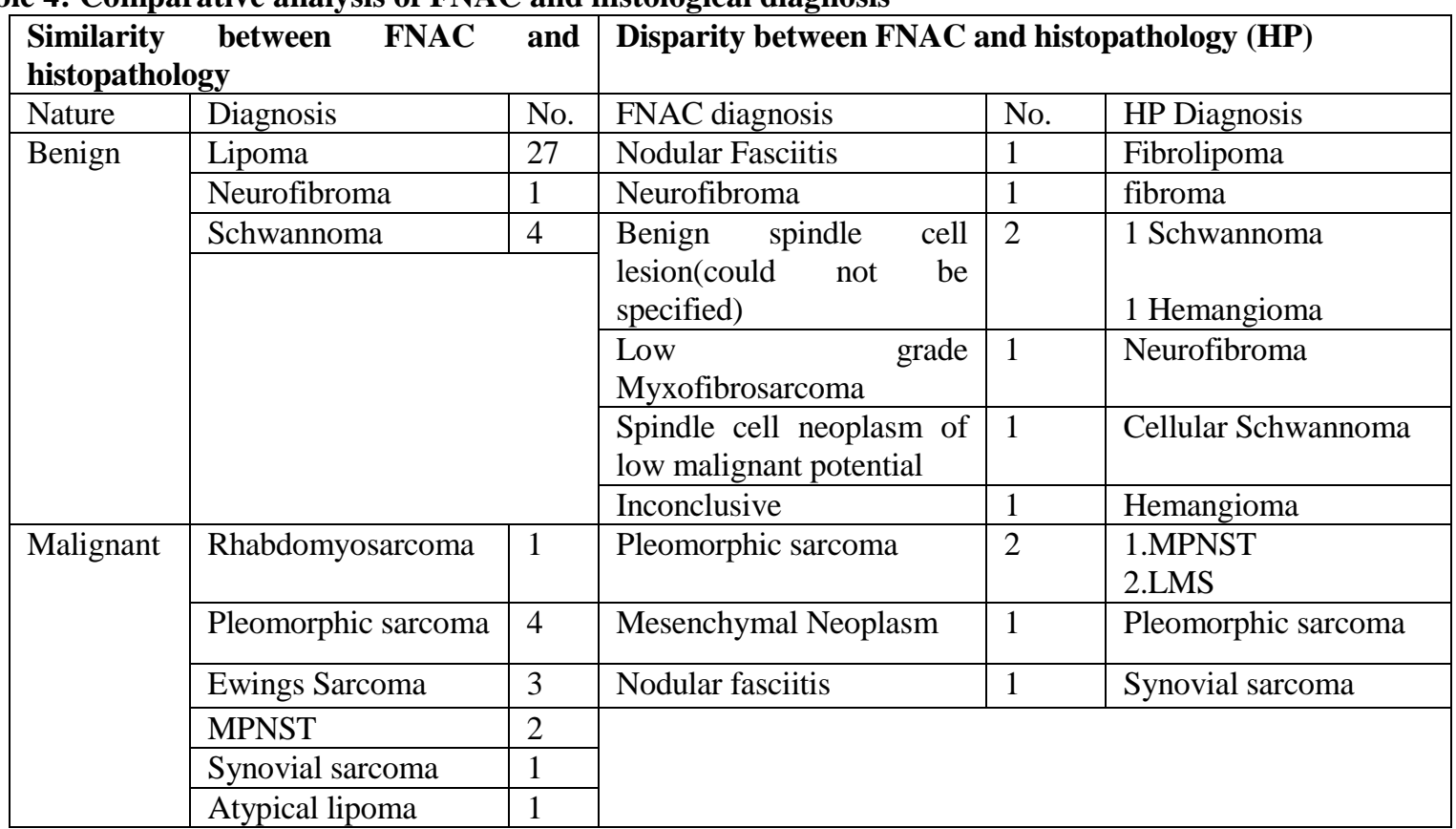

Table 5: Errors made in diagnosing soft tissue tumors

\begin{tabular}{|c|c|c|c|}
\hline & FNA & Histopathology & Reason of error \\
\hline $\begin{array}{l}\text { Inconclusive } \\
\text { FNA }\end{array}$ & Hemorrhagic & $\begin{array}{l}\text { Cavernous } \\
\text { hemangioma }\end{array}$ & Aspiration from blood filled spaces \\
\hline False negative & Nodular fascitis & Synovial sarcoma & $\begin{array}{l}\text { History of rapid increase in } \\
\text { swelling,tenderness } \\
\text { Cytology showing myofibroblast like } \\
\text { cells and myxoid background }\end{array}$ \\
\hline \multirow[t]{2}{*}{ False positive } & $\begin{array}{l}\text { Low grade } \\
\text { myxofibrosarcoma }\end{array}$ & neurofibroma & $\begin{array}{l}\text { Clinically large mass with history of } \\
\text { rapid enlargement } \\
\text { Cytology -spindle cells and cells } \\
\text { with multiple cytoplasmic } \\
\text { projections mimicking myofibroblast } \\
\text { and intercellular myxoid substance }\end{array}$ \\
\hline & $\begin{array}{l}\text { Spindle cell neoplasm of } \\
\text { low malignant potential }\end{array}$ & $\begin{array}{l}\text { Cellular } \\
\text { schwanoma }\end{array}$ & Atypia of nuclei and mitotic Fig.s \\
\hline \multicolumn{4}{|l|}{ Typing error } \\
\hline $\begin{array}{l}\text { Mesenchymal } \\
\text { tumour }\end{array}$ & & Organized abscess & $\begin{array}{l}\text { Pleomorphic } \\
\text { nuclei,myxoidfibrocollagenous } \\
\text { component and inflammation in the } \\
\text { backgound }\end{array}$ \\
\hline \multicolumn{4}{|l|}{ Subtyping error } \\
\hline & $\begin{array}{l}\begin{array}{l}\text { Benign spindle cell } \\
\text { tumor }\end{array} \\
\end{array}$ & $\begin{array}{l}\text { Cavernous } \\
\text { hemangioma }\end{array}$ & $\begin{array}{l}\text { Scant cellular material, only few } \\
\text { spindle cells aspirated }\end{array}$ \\
\hline & $\begin{array}{lll}\begin{array}{l}\text { Benign } \\
\text { tumor }\end{array} & \text { spindle cell } \\
\end{array}$ & schwannoma & $\begin{array}{l}\text { Scant cellular material, only few } \\
\text { spindle cells aspirated }\end{array}$ \\
\hline & Nodular fascitis & fibrolipoma & $\begin{array}{l}\text { Aspiration from fibrous component } \\
\text { and myofibroblast like cells }\end{array}$ \\
\hline & neurofibroma & fibroma & Misinterpretation of cells \\
\hline & Pleomorphic sarcoma & MPNST & Severe nuclear atypia \\
\hline & Pleomorphic sarcoma & LMS & Severe nuclear atypia \\
\hline
\end{tabular}


Table 6: Accuracy, sensitivity, specificity, positive predictive value, negative predictive value of FNAC in primary diagnosis of mesenchymal lesion

\begin{tabular}{|l|c|}
\hline Primary diagnosis & No. of cases/Total cases \\
\hline True positive(FNAC M/HPE M) & $15 / 54$ \\
\hline True negative(FNAC B/HPE B) & $36 / 54$ \\
\hline False positive(FNAC M/HPE B) & $2 / 54$ \\
\hline False negative(FNAC B/HPE M) & $1 / 54$ \\
\hline Accuracy & $51 / 54(94.4 \%)$ \\
\hline Sensitivity & $93.75 \%$ \\
\hline Specificity & $94.74 \%$ \\
\hline Positive predictive value & $88.24 \%$ \\
\hline Negative predictive value & $97.3 \%$ \\
\hline
\end{tabular}

\section{Discussion}

The present study was aimed to find out the effectiveness of FNAC in the diagnosis of soft tissue tumours. Total of 56 cases were studied by FNAC. Out of 56 cases one case was excluded from the study as it turned out to be an organised abscess on histopathology. Out of 55 cases, 54 cases were reported while one $(1.8 \%)$ case was inconclusive due to aspiration of blood. Out of 54 cases, specific diagnosis was given to 52 cases while two cases were reported as benign spindle cell neoplasm.

The inconclusive FNAC was found to be cavernous hemangioma on histopathology. Aspiration of blood was the cause for inconclusive FNAC. Fine needle aspiration of hemangioma of any type yields plenty of venous blood is cited by Ackerman. ${ }^{12}$

The excluded case was found to be an organised abscess on histopathological examination which was wrongly reported as malignancy on cytology. Wrong diagnosis of malignancy was made on cytology due to misinterpretation of the reactive fibroblasts and histiocytesas neoplastic malignant cells. Maitra et $\mathrm{al}^{7}$ in their study misinterpreted reparative fibroblastic activity as neoplastic atypia.

Of the two cases which were labelled as benign spindle cell neoplasm not specified on cytology, one was diagnosed as cavernous hemangioma whereas the other as schwannoma on histopathological examination. The patient diagnosed as cavernous hemangioma had a swelling in the calf region and was deep. Characterisation of this tumour was not possible on FNAC as the tumour aspirate was predominantly hemorrhagic and constituted few benign spindle cells. In this case the spindle cells represented the endothelial cells and the cause for haemorrhage was the blood filled spaces. The difficulty in diagnosing hemangiomas was cited by Siddharaju et al. ${ }^{13}$ Another case which was diagnosed as schwannoma on histopathology had lesion on her sacral lesion and the lesion was slow growing and was present for 20 years. Type specific diagnosis in this case was not possible on FNAC because of scant cellular smears and predominance of blood. Only occasional tightly cohesive spindle cells clusters and occasional stromal fragments were present in the aspirate. The major problem in FNAC of neurilemmoma is to obtain sufficient material was also cited by Domanski et al. ${ }^{14}$

In this study, the majority of soft tissue tumours were found to be benign and of these, lipoma were the commonest variety $(74 \%)$ consistent with the result reported in other studies. ${ }^{9}, 18$ Lipomas commonly occur after the second decade of life. Soft tissue sarcomas occurred in all age group but common after the second decade of life. Upper extremity and trunk was the favoured sites for benign tumours. Lower extremities were the favoured site for malignant tumours as cited by other studies. ${ }^{9,} 18$

Accuracy was high for the diagnosis of lipomatoustumours and was comparable with studies of Akermanet al. ${ }^{20}$ Roy et al. ${ }^{9}$ and Arul et al. ${ }^{18}$ One case of fibrolipoma was wrongly diagnosed as nodular fasciitis. Wrong diagnosis of nodular fasciitis was given due to small size of lesion and aspiration of fibrous areas. The cells aspirated showed bipolar to multipolar cytoplasmic processes of spindle cells as well as myxoid background which has led to erroneous diagnosis Fig. 1a.

Schwannoma was the second most common soft tissue tumour in the present study. Four (67\%) cases were diagnosed correctly on cytology as neurilemmoma, one $(16.6 \%)$ diagnosed as benign spindle cell neoplasm and one (16.6\%) as spindle cell neoplasm of low malignant potential. The results were between the studies of Klijanienko et al. $^{21}$ and Domnaski et al. $^{22}$ where correct labelling of Schwannoma ranges from $38.2 \%$ to $84 \%$. One case was diagnosed as benign spindle cell neoplasm due to scant cellular material and other was falsely diagnosed as spindle cell neoplasm of low malignant potential Fig. 1b. because of mitotic activity seen in cytological smears which turned out to be cellular Schwannoma on histopathological examination. Domnaski et al. ${ }^{22}$ also reported false positive diagnoses in their study.The diagnostic smears in most cases of schwannoma contained spindle cells with wavy nuclei embedded in a fibrillar, occasionally collagenous, and/or myxoid matrix and Antoni A/Antoni B tissue fragments. A moderate to abundant admixture of round to oval cells 
was also frequent. Nuclear pallisading was also noted. Cytological findings correlated well with histological findings in the smears where cellularity was adequate.

Most of the malignant soft issue tumours were pleomorphic sarcoma. Malignant peripheral nerve sheath tumour (MPNST) constituted a significant proportion (19\%) of soft tissue sarcoma in our institute. Kar M et al. ${ }^{23}$ found $12 \%$ of soft tissue sarcomas as MPNST in their medical centre. In our study there were three cases of MPNST diagnosed histologically. Out of these two were diagnosed correctly. On FNAC, two were subtyped correctly while one was typed as pleomorphic sarcoma. One case presented with classical pattern, one with predominance of isolated cells and one as pleomorphic cell pattern. Welldifferentiated MPNST comprised of cell-rich cellular fragments, spindle-shaped cells with wavy and commalike naked nuclei, polymorphous oval to round cells mitotic figures, fibrillary, delicate stroma and background myxoid material. Anaplastic giant cells, intranuclear inclusions were found in one case. FNAC was a good test for the diagnosis of moderate to well differentiated tumours. However in poorly differentiated tumors exact subtyping was not possible. Klizanienko et al described the various cytomorphological features of MPNST in their study. ${ }^{24}$

Three case (19\%) of malignant soft tissue tumours in the present study belonged to Ewing's sarcoma group. Two were males and one female. The cytological appearance of this lesion was distinctive. Bakhos et al. ${ }^{25}$ highlighted the characteristic cell morphology of this family of tumors. All cases of Ewing's sarcoma/PNET were correctly diagnosed on cytology. Immmunhistochemistry was available in two cases against MIC-2 antigen aiding the diagnosis on histopathology. Ewings sarcoma/PNET of thoracopulmonary region is known as Askin'stumor. We had two cases of chest wall sarcomas. They hadcharacterstic clinical, radiological and cytological features as described in case reports by Askin et al., ${ }^{26}$ Oruc et al. ${ }^{27}$ and Gulati et al. ${ }^{28}$ Two type of cell population of large light cells and small dark cells were seen Fig. 2a. The large light cells had cytoplasmic vacuoles which were PAS positive, the small round cells had tendency for rosette formation. Correct typing of these round cell tumours on cytology was possible due to characteristic morphology of cells and clinicoradiological correlation. PAS staining on cytolological smears helped in the diagnosis. Antibody applied to MIC-2 antigen Fig. 2c was an important adjunct. In our study cytology correlated well with histology Fig. $2 \mathrm{~b}$ and a type specific diagnose was possible due to characterstic morphologic appearance of cells. Better correlation was due to better differentiation of tumor cells.

We had two cases $(12.5 \%)$ of synovial sarcoma (SS) in the present study. Both patients were young, one was male and other was female. The male patient presented with swelling calf region Fig. 2d. Out of two only one was correctly diagnosed on cytology. In the male patient peripheral calcification on radiological investigation helped in the diagnosis. The false negative diagnosis of nodular fasciitis was given to other case because of rapidly growing tumour size, tender and small mass, myofibroblast like cells and myxoid background on cytology Fig. 1c. Classic patterns of monophasic synovial sarcoma observed cytologically as dispersed or small clusters of cells with bland chromatin, inconscipicous nucleoli, oval to spindle shaped cytoplasm and branching tumour tissue fragments, capillary network Fig. 2e. Similar findings were observed in the corresponding histopathology sections Fig. 2f. Klizanienko et al. ${ }^{29}$ described the various cytomorphological features of synovial sarcoma.

In our study there was one case of rhabdomyosarcoma (RMS) in a six year female child in the right upper eyelid Fig. 3a. Almeida et al ${ }^{30}$ discussed the cytology of rhabdomyosarcoma. Clusters and isolated tumour cells were present. Smears revealed two types of cells - one with scant cytoplasm, pleomorphic nuclei, fine to coarse nuclear chromatin, occasional nucleoli and other type with large abundant cytoplasm and peripheral cytoplasmic vacuolation and evidence of rhabdomyoblastic differentiation Fig. $3 b$. Immunohistochemistry showed positivity for myogenin Fig. 3d. In the present study cytology correlated well with the histological findings Fig. 3c.

There was one case of leiomyosarcoma (LMS) near the right elbow joint Fig. 4a. The cytological findings were of pleomorphic sarcoma. This case was wrongly diagnosed as pleomorphic sarcoma on cytology. Histopathology supported with immunohistochemistry aided in the diagnosis of leiomyosarcoma. High grade tumours are difficult to typify. In the present case the cytological findings were not characteristic and the morphologic appearance on cytology suggested a high grade malignant neoplasm with spindle cell and histiocyte like pleomorphic tumour cells suggestive of pleomorphic sarcoma Fig. 4b. On histopathologic examination same pattern observed Fig. $4 \mathrm{c}$ and it show edimmunoreactivityto SMA (smooth muscle actin) Fig. $4 \mathrm{~d}$ which led to the diagnosis of leiomyosarcoma. Klizanienko et al. ${ }^{31}$ highlighted the problem in differentiating high grade neoplasm.

Soft tissue tumours exhibited specific cell patterns which helped in their diagnosis and subtyping. Many classification schemes have been proposed that allow limited subclasification of soft tissue tumours. Nguyen et al. have proposed a three category scheme: 1) pleomorphic cell tumours, 2) spindle cell tumours and 3) small round cell tumours. ${ }^{15}$ In the present study, pattern of 54 cases were studied on cytology. In benign tumours, Twenty seven cases of lipoma recapitulated the mature tissue pattern. Rest of the benign tumours were having spindle cell pattern. In malignant tumours, 
7 showed pleomorphic cell pattern, 5 showed spindle cell pattern and 4 showed round cell pattern. Study of tissue sections also revealed similar patterns as described on cytology. However, tissue sections had the advantage that large areas were examined and representative material from various areas were taken.

In the present study, total of 55 cases of soft tissue tumours were studied on FNAC and correlated by histopathology. Thirty seven were reported as benign, seventeen as malignant and one was inconclusive. One case of synovial sarcoma was reported as nodular fasciitis while false positive cases were neurofibroma and cellular schwannoma. The overall accuracy was $94.4 \%$ for both benign and malignant neoplasms. Diagnostic accuracy in the present study was comparable with the studies of Roy et al. ${ }^{9}$ and Arul et al. ${ }^{18}$

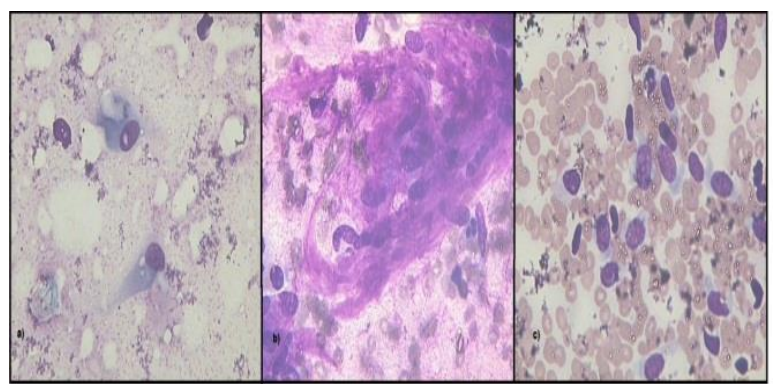

Fig. 1: (Giemsa stain, 400x). a) Myofibroblast like cells seen in fibrolipoma which were misinterpreted as a feature on nodular fascitis. b) Spindle cells showing mild atypia and myxiod substance in the background in a case of schwanomma misinterpreted as sign of mlignancy. c) Bland spindle cells and few myofibroblast like cells in synovial sarcoma misinterpreted as a feature of nodular fascitis.

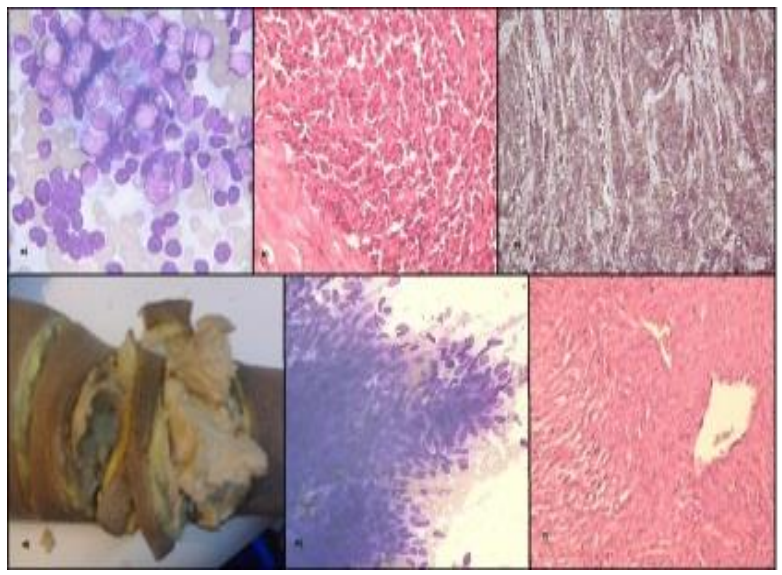

Fig. 2: (a-c, ewing's sarcoma), a) cytological smears showing large lighter cells and small darker cells (giemsa, 400x), b) corresponding histopathological section (h\&E,200x), c) immunohistochemistry showing positivity for MIC-2. (d-f, synovial sarcoma), d) cut section of growth in calf region, e) cytology showing branching fragments of bland spindle cells (giemsa,400x), f) corresponding histopathological section $(\mathrm{h} \& \mathrm{E}, \mathbf{4 0 0 x})$.

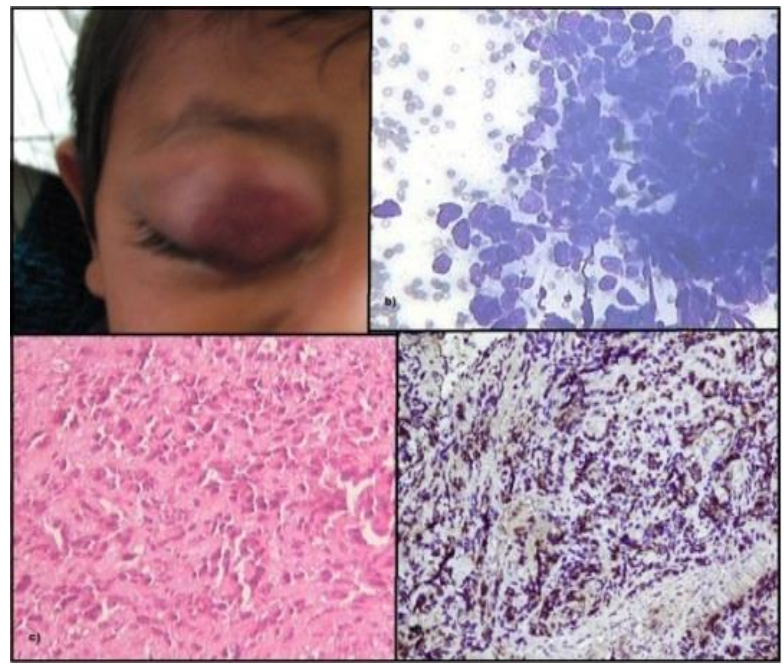

Fig. 3: Rhabdomyosarcoma. a) clinical presentation as swelling upper eye lid, b) cytosmears showing tumor cells in isolation and in clusters with pleomorphic nuclei and cytoplasmic vacolation (giemsa,400x), c) corresponding histopathological section (h\&E,400x), d) immunohistochemistry showing positivity for myogenin $(200 x)$.

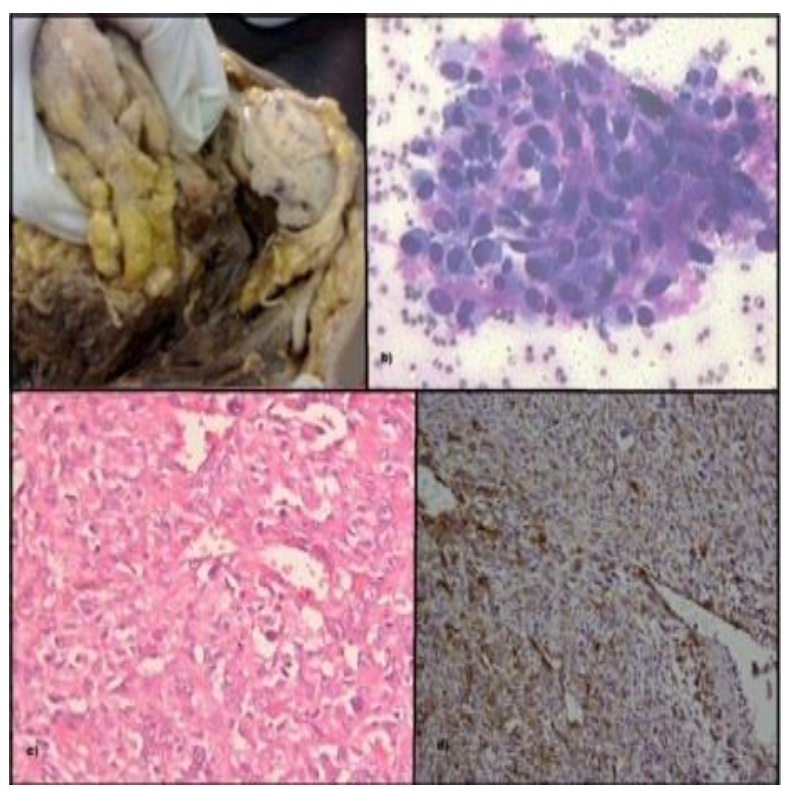

Fig. 4: Leiomysarcoma. a) cut section of growth elbow, b) cytosmears showing pleomorphic spindle to polygonal cells (giemsa,400x), c) corresponding histopathology section (h\&E,400x) d) immunohistochemistry showing positivity for smooth muscle actin (200x). 


\section{Conclusion}

FNAC is a useful test in the initial management of soft tissue neoplasms as it is fairly accurate. FNA of soft tissue tumours yields specific cell pattern which help in their categorisation and subtyping. However, different types of tumours having similar cell pattern poses diagnostic difficulties and careful interpretation of cytological findings is required. Histopathological examination aided with immunohistochemistry is required for exact characterisation and grading which helps in deciding further treatment and final outcome.

\section{Conflict of Interest: None}

\section{References}

1. Patel MM, Patel SM, Jana S, Mansoori B, Shah P, Kevadiya S. Fine needle aspiration cytology of soft tissue tumours, its accuracy and pitfalls--our institutional experience. SEAJCRR 2014;3:881-89.

2. Cardoso P, Rosa J, Esteves J, Oliviera J, RodriguesPinto R. Fine needle aspiration for the diagnosis and treatment of musculoskeltal tumours. Acta Orthopaedicaet Traumatologica Turcica 2017;51:27883.

3. Beg S, Vasenwala SM, Haider N, Ahmed SS, Maheswari V, Khan MA et al. A comparison of cytology and histopathological findings and role of immunostains in the diagnosis of soft issue tumours. $J$ Cytol 2012;29:125-30.

4. Khalbuss WE, Teot LA, Monaco SE. Diagnostic accuracy and limitations of fine-needle aspiration cytology of bone and soft tissue lesions: a review of 1114 cases with cytological-histological correlation. Cancer Cytopathol 2010;118:24-32.

5. Akerman M. Fine needle aspiration cytology of soft tissue sarcoma: benefits and limitations. Sarcoma 1998;2:155-61.

6. Singh HK, Kilpatric SE, Silverman JF. Fine needle aspiration biopsy of soft tissue sarcomas: utility and diagnostic challenges. Adv Anat Pathol 2004;11:24-37.

7. Maitra A, Ashfaq R, Saboorian MH, Lindberg G, Gokaslan ST. The Role of Fine-Needle Aspiration Biopsy in the Primary Diagnosis of Mesenchymal Lesion. Cancer Cytopathol 2000;90:178-85.

8. Bezabih M. Cytological diagnosis of soft tissue tumors. Cytopathology 2001;12:177-83.

9. Roy S, Manna AK, Pathak S, Guha D. Evaluation of fine needle aspiration cytology and its correlation with histopathological findings in soft tissue tumours. $J$ Cytol 2007;24:37-40.

10. Kumar S, Chowdhury N. Accuracy, limitation and pitfalls in the diagnosis of soft tissue tumors by fine needle aspiration cytology. Indian J Pathol Microbiol 2007;50:42-5.

11. Gonzalez-Campora R. Cytoarchitectural Findings in the Diagnosis of Soft Tissue Tumors. Acta Cytol 2001;45:115-46.

12. Ackerman M. Soft tissue. In:OrellSR, Stervett GI,Whitaker D editors. Fine needle aspiration cytology $4^{\text {th }}$ edition. New delhi: Elsevier, 2005:423.

13. Siddharaju N, Solo S, Badhe BA, Sriniwasan R. Benign skin adenexaltumorvshemangioma: diagniostc pitfall due to cytological sampling error. Actacytol 2008.

14. Domanski HA, AkermanM, Engellau J, Gustafson P, Mertens F, Rydholm A. et al. A fine needle aspiration of neurolimmoma (schwannoma)

Aclinicocytopathologic study of 116 patients. Diagn Cytopathol 2006;34:403-12.

15. Nguyen Gk. What is the value of fine needle aspiration inthe cytodiagnosis of soft tissue tumours? Diagn Cytopathol 1988;4:352-55.

16. Ogun GO. Fine needle aspiration biopsy (FNAB) in the initial evaluation and diagnosis of palpable soft tissue lesions and with histologic correlation. Pan African Med J 2015;20:44.

17. Jain V, Agarwal T. Role of FNAC in soft tissue tumors and its histopathological correlation. Int Surg J 2017;4:2632-2636

18. Arul P, Masilamani S. Fine needle aspiration cytology of soft tissue tumors with its histopathological correlation in rural hospital of south india: a retrospective study. Clin Cancer Investing $J$ 2016;5:146-150.

19. Kaur I, Handa U, Kundu R, Garg SK, Mohan H. Role of fine needle aspiration cytology and core needle bopsy in diagnosing musculoskeletal neoplasms. $J$ Cytol 2016;33:7-12.

20. Akerman M, Rydholm A. Aspiration Cytology of LipomatousTumor: A 10-year Experience at an Orthopaedic Oncology centre. Diagn Cytopathol 1987;3:295-302.

21. Klijanienko J, Caillaud JM, Lagacé R. Cytohistologic correlations in schwannomas (neurilemmomas), including "ancient," cellular, and epithelioid variants. Diagn Cytopathol 2006;34(8):517-22.

22. Domanski HA, Akerman M, Engellau J, Gustafson P, Mertens F, Rydholm A. et al. Fine-needle aspiration of neurilemoma (schwannoma). A clinicocytopathologic study of 116 patients. Diagn Cytopathol 2006;34:40312.

23. Kar M, Deo SVS, Shukla NK, Malik A, Dattagupta S, Mohanti BK, et al. Malignant peripheral nerve sheath tumors (MPNST)- Clinicopathological study and treatment outcome of twenty-four cases. World J Surg Oncol 2006;4:55

24. Klizanienko J, Caillaud JM, Lagace R, Vielh P. Cytohistologic correlation of 24 malignant peripheral nerve sheath tumors(MPNST)in 17 patients. Diagn Cytopathol 2002;27:103-08.

25. Bakhos R, Andrey J, Bhoopalam N, Jensen J, Reyes $\mathrm{CV}$ et al. Fine-needle aspiration cytology of extraskeletal Ewing's sarcoma. Diagn Cytopathol 1998;18:137-40.

26. Askin FB, Rosai J, Sibley RK, Dehner LP, McAlister WH. Malignant small cell tumor of the thoracopulmonary region in childhood: a distinctive clinicopathologic entity of uncertain histogenesis. Cancer 1979;43:2438-51.

27. Oruc O, Hocahoglu A, Caglayan B, Ozlagan ES, Erdogan N. AskinTumor: Malignant Round Cell Tumor in theThoracopulmonary Region. Turkish Respir J 2002;3:109-12.

28. Gulati D, Bahal A, Dhar AK, Chakravorty N, Muttagikar MP, Lakhtakia R. AskinRosai Tumour. MJAFI 2007;63:284-85.

29. Klizanienko J, Caillaud JM, Lagace R, Vielh P. Cytohistological correlations in 56 synovial sarcomas in 36 patients: The Institut Curie experience. Diagn Cytopathol 2002;27:96-102.

30. Almeida MD, Stastny JF, Wakely PE, Frable WJ. Fineneedle aspiration biopsy of childhood rhabdomyosarcoma: Reevaluation of the cytologic criteria for diagnosis. Diagn Cytopathol 1994;11:231-6 
31. Klizanienko J, Caillaud JM, Lagace R, Vielh P. FineNeedle Aspiration of Leiomyosarcoma: A Correlative Cytohistologic Study of 96 Tumors in 68 Patients. Diagn Cytopathol 2003;28:119-25.
How to cite the article: Singh S, Sharma J, Mardi K, Jaswal K.S Panwar R. Diagnostic value of fine needle aspiration cytology in the evaluation of soft tissue tumours. Arch Cytol Histopathol Res 2018;3(4):219226. 